\title{
Hubungan antara Besarnya Defek Septum Ventrikel dengan Fungsi Paru
}

\author{
Nurlina Kumala Sari, Anindita Soetadji, M.Sholeh Kosim \\ Departemen Ilmu Kesehatan Anak Fakultas Kedokteran Universitas Diponegoro/RSUP dr. Kariadi, \\ Semarang
}

\begin{abstract}
Latar belakang. Pada anak dengan defek septum ventrikel (DSV), terjadi peningkatan aliran darah ke paru. Semakin besar DSV, semakin meningkat aliran darah ke paru maka risiko infeksi saluran pernafasan akut dan gagal jantung meningkat dan menganggu fungsi paru. Fungsi paru yang baik penting untuk pemeliharaan suplai oksigen saat sebelum dan setelah dilakukan operasi. Spirometri merupakan alat yang penting dan praktis dalam menilai fungsi paru. Perbandingan $\mathrm{FEV}_{1} / \mathrm{FVC}$ digunakan untuk mendiagnosis dan membedakan antara penyakit paru obstruktif dan restriktif.

Tujuan. Membuktikan adanya hubungan antara besarnya DSV, flow ratio, klasifikasi gagal jantung, frekuensi infeksi respiratori akut (IRA), dan status gizi dengan fungsi paru.

Metode. Dilakukan penelitian observasional dengan pendekatan cross-sectional di RS dr. Kariadi dari bulan September 2011 sampai dengan Desember 2012. Subjek anak dengan DSV yang belum dilakukan operasi, umur 5-14 tahun yang mendapat terapi di instalasi rawat jalan RS dr. Kariadi. Dilakukan ekokardiografi untuk mengukur diameter DSV dan flow ratio $(\mathrm{Qp} / \mathrm{Qs})$ dan spirometri untuk menilai fungsi paru melalui pengukuran $\left(\mathrm{FEV}_{1} / \mathrm{FVC}\right)$. Analisis statistik dengan uji korelasi Spearman dan uji Fisher's Exact.

Hasil. Subjek terdiri atas 20 anak dengan DSV (65\% perempuan). Rerata diameter DSV 12,32 mm (SB 9,18), rerata dari flow ratio 2,63 (SB 0,92), rerata frekuensi IRA 4,60 kali (SB 2,98). Rerata FEV $/$ /FVC adalah 94,1\% (SB 9,82). Ukuran DSV besar, flow ratio yang tinggi, dan seringnya IRA mempunyai risiko tinggi untuk terjadinya gangguan fungsi paru restriktif, secara berturut-turut dengan $\mathrm{RP}=1,5$ ( $\mathrm{p}=0,038), \mathrm{P}=1,8$ $(\mathrm{p}=0,009), \mathrm{RP}=1,5$ ( $\mathrm{p}=\mathbf{0 , 0 3 8 )}$. Status gizi berhubungan sedang dengan fungsi paru $(\mathrm{r}=\mathbf{0 , 6 0 4 ,} \mathrm{p}=\mathbf{0 , 0 0 5})$.

Kesimpulan. DSV besar, flow ratio, frekuensi IRA, dan status gizi berhubungan dengan fungsi paru.

Sari Pediatri 2014;16(3):189-94
\end{abstract}

Kata kunci: defek septum ventrikel, fungsi paru, spirometri

Alamat korespondensi:

Dr. Nurlina Kumala Sari, Sp.A. RSUD Sukamara. Jl. Tjilik Riwut Km 5,5, Sukamara, Kalimantan Tengah. Telp/Fax. (0532) 26752. E-mail: dr_linsay@yahoo.com
$\mathrm{P}$ enyakit jantung bawaan (PJB) merupakan kelainan bawaan yang sering dijumpai, angka kejadian 30\% dari seluruh kelainan bawaan. Insiden PJB di negara maju maupun berkembang, berkisar 6-10 kasus per 1000 kelahiran hidup dengan rata-rata 8 per 1000 kelahiran hidup. 
Penelitian Sastroasmoro dkk, ${ }^{1}$ di Poliklinik Kardiologi Ilmu Kesehatan Anak Fakultas Kedokteran Universitas Indonesia (FKUI)/ RS Dr. Cipto Mangunkusumo (RSCM) Jakarta, dijumpai 2901 kasus PJB di antara 3602 pasien baru yang diperiksa selama 10 tahun (1983 s/d 1992). Berdasarkan tipe PJB, PJB asianotik, 602 $(76,7 \%)$ kasus, merupakan jenis yang terbanyak.

Di Poliklinik Anak Sub Bagian Kardiologi RS Dr. Kariadi (RSDK) Semarang, pada periode Januari 2007 sampai dengan Desember 2008 dijumpai 135 pasien baru PJB (belum termasuk pasien PJB yang datang langsung ke Unit Penyakit Jantung RSDK). Jumlah tersebut bisa saja lebih sedikit dari jumlah nyata angka kejadian PJB yang sebenarnya dan tercatat. Penyakit jantung bawaan asianotik, terdapat 109 (80,7\%) pasien dan 55 (50,37\%) dengan DSV, merupakan yang terbanyak. Sifat khusus kelainan DSV adalah tidak terdapat sianosis, aliran darah ke arteri pulmonalis lebih banyak, dan terdapat pirau pada ventrikel. Gambaran klinisnya tergantung dari besar kecilnya defek pada ventrikel tersebut. Semakin besar defek, semakin banyak darah yang masuk ke arteri pulmonalis sehingga tekanan pada arteri pulmonalis semakin tinggi dan juga terjadi peningkatan tahanan pada kapiler paru-paru. Dengan demikian, berat ringannya manifestasi klinis pada anak dengan DSV tergantung pada besarnya pirau tersebut, meliputi diameter DSV dan tingkat resistensi vaskular paru. $^{2}$

Masih sangat jarang dilaporkan fungsi respirasi pada anak dengan DSV. Padahal, anak dengan DSV sering disertai penyulit berupa infeksi respiratori akut (IRA) dan apabila terkena, akan lebih lama sembuh dibandingkan anak normal. Gagal jantung memperburuk keadaan tersebut. Infeksi saluran napas ini sering berlanjut menjadi pneumonia. Hal tersebut juga sulit dibedakan dengan gagal jantung. Infeksi saluran napas berulang lebih sering terjadi pada bayi yang berusia kurang dari satu tahun dibandingkan dengan pasien yang lebih tua. Salah satu cara untuk menilai fungsi paru adalah dengan mengukur Force expiratory volume detik pertama $\left(F E V_{1}\right)$ dan force vital capacity $(F V C)$. P engukuran ini sudah dapat mewakili suatu gangguan respirasi yang bersifat obstruktif maupun restriktif. ${ }^{3}$

Tujuan penelitian ini untuk mengetahui hubungan antara besarnya defek septum ventrikel melalui pengukuran ekokardiografi dengan fungsi paru melalui pengukuran force Expiratory volume detik pertama $\left(\mathrm{FEV}_{1}\right) /$ force vital capacity (FVC) pada anak.

\section{Metode}

Penelitian observasional dengan desain potong lintang (cross sectional) yang dilakukan di poliklinik dan rawat inap Divisi Kardiologi Departemen Ilmu Kesehatan Anak FK UNDIP/RSDK selama bulan September 2011 sampai dengan Desember 2012. Penelitian telah mendapat persetujuan Komisi Etik Penelitian Kesehatan Fakultas Kedokteran Universitas Diponegoro dan RSUP dr. Kariadi Semarang tanggal 14 September 2011 dengan nomor 151/EC/FK/ RSDK/2011. Persetujuan untuk diikutsertakan dalam penelitian dimintakan dari orang tua pasien dengan menggunakan informed consent secara tertulis.

Pengambilan sampel dilakukan secara konsekutif. Kriteria inklusi adalah anak dengan defek septum ventrikel berumur 5 sampai dengan 14 tahun, belum menjalani operasi jantung, bisa melakukan spirometri, bersedia menaati prosedur penelitian, tidak menderita gagal jantung Ross IV, tidak menderita COPD (chronic obstruktif pulmonary disease). Dilakukan aloanamnesis terhadap orang tua dan pemeriksaan fisik, kemudian dilakukan klasifikasi derajat gagal jantung berdasarkan kriteria Ross, pemeriksaan hemoglobin, pemeriksaan ekokardiografi dilakukan di Unit Penyakit Jantung RSDK dengan Aloka a 10 oleh spesialis kardiologi anak, dilakukan pencatatan besar DSV, flow ratio, dan pemeriksaan spirometri dibagian Rehabilitasi Medik RSDK dengan Spirometri ENRAF Monius Model Spiro 601.

Analisis data meliputi analisis deskriptif dan uji hipotesis. Pada analisis deskriptif, data yang berskala kategorial, seperti jenis kelamin anak, umur, dan sebagainya dinyatakan sebagai distribusi frekuensi dan persentase. Sementara itu, variabel yang berskala kontinyu, seperti umur dan sebagainya dinyatakan sebagai rerata dan simpang baku atau median. Dilakukan analisis dengan uji Spearman untuk data yang berskala numerik dan uji Fisher Exact untuk data yang berskala nominal. Seluruh proses analisis data dilakukan dengan menggunakan program komputer.

\section{Hasil}

Diperoleh 20 anak DSV, terdiri atas 13 (65\%) perempuan dan 7 (35\%) laki-laki. Rerata usia subjek adalah 7,95 tahun dengan usia termuda 5 tahun dan tertua 13 tahun. Karakteristik sampel penelitian tertera pada Tabel 1 . 
Tabel 1. Karakteristik subjek dan hasil pengukuran

\begin{tabular}{llc}
\hline Variabel & $\mathrm{n}(\%)$ & Rerata (SB) \\
\hline Jenis kelamin & & \\
$\quad$ Laki-laki & $7(35)$ & \\
$\quad$ Perempuan & $13(65)$ & \\
Usia (tahun) & & $7,95(2,8)$ \\
Berat badan (kg) & & $18,91(7,2)$ \\
Tinggi badan (cm) & & $117,72(13,09)$ \\
Diameter DSV (mm) & & $17,74(2,6)$ \\
Flow ratio (Qp/Qs) & & $2,63(0,92)$ \\
Frekuensi IRA (kali) & & $4,60(2,98)$ \\
Klasifikasi gagal jantung & & \\
Ross I & $6(30)$ & \\
Ross II & $9(45)$ & \\
Ross III & $5(25)$ & \\
Status gizi & & \\
Baik & $12(60)$ & \\
Kurang & $6(30)$ & \\
Buruk & $2(10)$ & \\
Hemoglobin (g/\%) & & $12,94(0,76)$ \\
FEV1 (\%) & & $84,05(68,35)$ \\
FVC (\%) & & $84,80(56,64)$ \\
FEV1/FVC (\%) & & $94,12(9,82)$ \\
Interpretasi spirometri & & \\
Severe restrictive & $4(20)$ & \\
Moderate restrictive & $5(25)$ & \\
Mild restrictive & $6(30)$ & \\
Normal & $5(25)$ & \\
\hline
\end{tabular}

Interpretasi spirometri mendapatkan hasil sampel yang mengalami fungsi paru restiktif, yaitu 4 subjek mengalami severe restrictive, 5 moderate restrictive, 6 mild restrictive, dan 5 dengan kesan spirometri normal.

Tabel 2 menunjukkan terdapat hubungan cukup kuat (moderate correlation) antara status gizi dan fungsi paru dengan koefisien korelasi $\mathrm{r}=0,604(\mathrm{p}=0,005)$, tidak terdapat hubungan antara gagal jantung, hemoglobin, dan fungsi paru dengan koefisien korelasi berturut-turut $\mathrm{r}=0,411(\mathrm{p}=0,072), \mathrm{r}=-0,380(\mathrm{p}=0,098)$. Tidak dijumpai kelainan dinding dada pada seluruh subjek penelitian.

Tabel 3 menunjukkan $\mathrm{RP}=1,5$ ( $\mathrm{p}=0,038)$, terdapat hubungan antara besarnya DSV dengan fungsi paru melalui pengukuran $\mathrm{FEV}_{1} / \mathrm{FVC}$. Anak dengan diameter DSV $>10 \mathrm{~mm}^{2} / \mathrm{m}^{2} \mathrm{BSA}$ memiliki risiko untuk menderita gangguan fungsi paru 1,5 kali lebih besar daripada anak dengan diameter DSV $5-10 \mathrm{~mm}^{2} / \mathrm{m}^{2} \mathrm{BSA}$. Terdapat hubungan antara flow ratio $(\mathrm{Qp} / \mathrm{Qs})$ dengan fungsi paru, $\mathrm{RP}=1,8(\mathrm{p}=0,009)$, melalui pengukuran $\mathrm{FEV}_{1} /$ FVC pada anak dengan DSV. Anak dengan flow ratio $>1,5$ memiliki risiko untuk menderita gangguan fungsi

Tabel 2. Hubungan variabel perancu dengan fungsi paru

\begin{tabular}{lcc}
\hline Variabel & $\mathrm{r}$ & $\mathrm{p}$ \\
\hline Gagal jantung & 0,411 & 0,072 \\
Status gizi & 0,604 & $0,005^{*}$ \\
Kadar hemoglobin & $-0,380$ & 0,098 \\
\hline
\end{tabular}

*Di analisis dengan Spearman Correlation Test, korelasi signifikan

Tabel 3. Hubungan antara diameter DSV, Flow ratio, dan frekuensi IRA dengan fungsi paru

\begin{tabular}{|c|c|c|c|c|c|}
\hline \multirow{2}{*}{ Variabel } & \multicolumn{3}{|c|}{ Gangguan fungsi paru } & \multirow[b]{2}{*}{$\mathrm{RP}$} & \multirow[b]{2}{*}{$\mathrm{p}$} \\
\hline & Ya & Tidak & Total & & \\
\hline \multicolumn{6}{|c|}{ Diameter DSV $\left(\mathrm{mm}^{2} / \mathrm{m}^{2} \mathrm{BSA}\right)$} \\
\hline $5-10$ & 6 & 4 & 13 & \multirow{2}{*}{1,5} & \multirow{2}{*}{$0,038^{*}$} \\
\hline$>10$ & 9 & 1 & 10 & & \\
\hline \multicolumn{6}{|c|}{ Flow ratio (Qp/Qs) } \\
\hline$\leq 1,5$ & 1 & 3 & 4 & \multirow{2}{*}{1,8} & \multirow{2}{*}{$0,009^{*}$} \\
\hline$>1,5$ & 15 & 1 & 16 & & \\
\hline \multicolumn{6}{|c|}{ Frekuensi IRA (kali/tahun) } \\
\hline$<5$ & 6 & 4 & 13 & \multirow{2}{*}{1,5} & \multirow{2}{*}{$0,038^{\star}$} \\
\hline$>5$ & 9 & 1 & 10 & & \\
\hline
\end{tabular}

*Di analisis dengan Fisher's Exact Test, hubungan signifikan Rasio prevalensi (RP) dihitung berdasarkan rumus: $\mathrm{a} / \mathrm{a}+\mathrm{b}: \mathrm{c} / \mathrm{c}+\mathrm{d}$. BSA: (Body Surface Area) 
paru 1,8 kali lebih besar daripada anak dengan flow ratio $<1,5$. Terdapat hubungan antara frekuensi IRA dengan fungsi paru, $\mathrm{RP}=1,5(\mathrm{p}=0,038)$, melalui pengukuran $\mathrm{FEV}_{1} / \mathrm{FVC}$ pada anak dengan DSV. Anak dengan DSV yang menderita IRA $>5$ kali/tahun mempunyai kecenderungan 1,5 kali lebih besar untuk terjadinya gangguan fungsi paru dibanding anak dengan DSV yang menderita IRA $<5 \mathrm{kali} /$ tahun.

\section{Pembahasan}

Keterbatasan dan kendala penelitian ini adalah alat spirometri dengan mouth piece berdiameter $3 \mathrm{~cm}$ yang tersedia kurang sesuai (terlalu besar) dan jumlah sampel yang kurang banyak karena keterbatasan waktu.

Secara garis besar didapatkan hubungan antara diameter DSV, flow ratio, status gizi, serta frekuensi IRA terhadap gangguan fungsi paru. Namun, faktor yang paling berpengaruh terhadap fungsi paru tersebut belum bisa ditentukan karena keterbatasan jumlah sampel. Dengan demikian, tidak dapat dilakukan analisis multivariat dengan regresi logistik untuk menentukan faktor apa yang paling memengaruhi gangguan fungsi paru. Dimungkinkan, antara faktorfaktor tersebut saling berhubungan atau berdiri sendiri dalam memengaruhi gangguan fungsi paru. Hal tersebut sesuai dengan pernyataan Putra, ${ }^{9}$ bahwa banyak faktor - umur, jenis kelamin, lamanya menderita penyakit jantung bawaan, kadar hemoglobin, status gizi, seringnya menderita infeksi saluran pernafasan akut, serta derajat gagal jantung - yang memengaruhi fungsi respirasi dengan penyakit jantung bawaan pirau kiri ke kanan.

Hollenberg $\mathrm{dkk}^{5}$ menyebutkan bahwa penderita dengan gagal jantung kongestif akan terjadi penurunan force expiratory volume pada detik pertama $\left(\mathrm{FEV}_{1}\right)$ dan nilai Oxygen Uptake Eficiency Slope (OUES) lebih rendah dibandingkan dengan subjek yang tidak memiliki penyakit kardiovaskular. Kimball $\mathrm{dkk}^{6}$ meneliti hubungan dari gejala kontraktilitas dan besarnya defek pada anak dengan DSV. Hasil penelitian Kimball mendapatkan besaran defek lebih dari $0,5 \mathrm{~cm}$ (luas ukuran defek dibandingkan dengan luas permukaan tubuh lebih dari $1,8 \mathrm{~cm} / \mathrm{m}^{2}$ ). Hal tersebut merupakan awal gejala gangguan kontraktilitas jantung pada anak dengan DSV yang ditandai dengan kongesti pulmonal sehingga mulai akan terjadi gangguan respirasi.

Faridi $\mathrm{dkk}^{15}$ menemukan bahwa penurunan $\mathrm{FEV}_{1}$ dan FVC pada anak dengan malnutrisi, FVC, FEV1, dan PEFR menunjukkan hubungan linier dengan indeks massa tubuh pada semua grup yang diteliti. Anak dengan malnutrisi akan menginterpretasikan fungsi respirasi yang abnormal. Milla ${ }^{16}$ meneliti hubungan status nutrisi dengan fungsi pulmoner pada anak dengan fibrosis kistik. Penelitian Milla menyatakan bahwa status nutrisi berhubungan erat dengan kesehatan pulmoner pada pasien fibrosis kistik. Oleh karena itu, dukungan nutrisi yang agresif mendukung pertumbuhan menjadi normal sehingga perkembangan paru dan pemeliharaan kesehatan pulmoner menjadi adekuat.

Tidak terdapat hubungan kadar hemoglobin dengan penurunan fungsi paru karena pada semua subjek penelitian didapatkan rerata hemoglobin yang bukan merupakan keadaan anemia. Dengan demikian, kebutuhan oksigen untuk sirkulasi dan metabolisme dapat tercukupi dengan baik.

Pada penelitian ini juga tidak didapatkan hubungan antara gagal jantung dengan fungsi paru, kemungkinan karena kondisi gagal jantung telah terkompensasi (stabil) dengan pemakaian obat gagal jantung. Kemungkinan lain karena jumlah sampel yang kurang banyak sehingga tidak didapatkan hubungan antara gagal jantung dengan fungsi paru.

Terdapat hubungan antara flow ratio (Qp/Qs) dengan fungsi paru dan hubungan antara frekuensi IRA dengan fungsi paru. Sesuai dengan hasil tersebut, Healy $\mathrm{dkk}^{11}$ mengemukakan bahwa adanya pirau akan menyebabkan peningkatan berlebih dari aliran darah pulmonal dan peningkatan aliran balik darah vena. Komplikasi jangka panjang, meliputi disfungsi diastolik ventrikel kiri dan kardiomiopati dilatasi yang menyebabkan kompresi jalan napas. Pirau kiri ke kanan akan meningkatkan aliran darah pulmonal yang menyebabkan rentensi air dalam paru (edema pulmonal). Edema pulmonal diakibatkan oleh gangguan gaya Starling (tekanan hidrostatik dan onkotik) yang mengatur aliran air antara kapiler dan alveoli. Peningkatan gaya hidrostatik di dalam kapiler paru akan meningkatkan tekanan pendorong keluarnya cairan dari kapiler, menyebabkan alveoli tidak stabil dan membuat paru menjadi kaku (penurunan komplians paru) sehingga akan meningkatkan usaha pernapasan guna mempertahankan ventilasi yang adekuat.

Menurut penelitian Yau dkk, ${ }^{17}$ anak dengan penyakit jantung bawaan mempunyai risiko lebih tinggi terkena virus infeksi pernafasan bagian bawah, 
sebab kelainan anatomi jantung dapat menyebabkan status respiratori menjadi lebih buruk.

Geskey $\mathrm{dkk}^{18}$ meneliti bahwa infeksi respiratory syncitial virus (RSV) dapat meningkatkan komplikasi jantung yang menyebabkan anak harus menjalani perawatan di rumah sakit. Murray ${ }^{18}$ meneliti bahwa variabel penting yang dihubungkan dengan perawatan rumah sakit karena infeksi respiratori akut tidak dihubungkan dengan tipe kelainan jantung (sianotik atau asianotik penyakit jantung bawaan), melainkan dihubungkan dengan anak yang mempunyai berat badan di bawah persentil 3 sesuai umurnya, mempunyai saudara yang sedang menderita infeksi respiratori akut di rumah, serta kelainan kromosom seperti trisomi 21.

Tes spirometri menunjukkan 15 dari 20 subjek penelitian mengalami gangguan fungsi paru restiktif, yang berarti gangguan respirasi pasien DSV bukan berasal dari paru-paru itu sendiri melainkan di luar paru yang mengganggu daya pengembangan paru. Hasil tersebut sesuai dengan penelitian Opotowsky ${ }^{20}$ bahwa abnormalitas spirometri pada penderita penyakit jantung bawaan pirau kiri ke kanan adalah terjadinya penurunan komplians dinamik dan terjadi peningkatan resistensi jalan nafas. Perubahan mekanik pada paru ini berkorelasi dengan cincin vaskular pulmoner daripada derajat hipertensi pulmonal.

Pernyataan Opotowsky $\mathrm{dkk}^{20}$ bahwa dari aspek mekanika terdapat dua macam gangguan ventilasi, yaitu gangguan yang bersifat obstruktif dan restriktif. Gangguan obstruktif adalah gangguan yang menyebabkan terhalangnya kelancaran arus udara (air flow) yang masuk atau ke luar paru, kelainan umumnya terletak pada saluran respiratorik. Sementara itu, gangguan restriktif adalah yang menyebabkan berkurangnya volume paru (lung volume), kelainan umumnya terletak di luar saluran respiratorik. Beberapa penyakit dapat menimbulkan gangguan obstruktif dan restriktif secara bersamaan. Selain itu, gangguan ventilasi dapat berupa gangguan terhadap upaya inspirasi, upaya ekspirasi, atau keduanya.

\section{Kesimpulan}

Terdapat hubungan antara diameter DSV, flow ratio, frekuensi IRA, status gizi dengan fungsi paru. Diameter DSV $>10 \mathrm{~mm}^{2} / \mathrm{m}^{2}$ BSA mempunyai risiko untuk terjadinya gangguan fungsi paru restriktif 1,5 kali dibandingkan dengan diameter DSV $5-10 \mathrm{~mm}^{2} /$ $\mathrm{m}^{2} \mathrm{BSA}$. Disarankan terapi fisik pada anak dengan DSV untuk memperbaiki pengembangan paru serta melatih otot - otot pernafasan agar fungsi paru menjadi lebih baik. Terapi fisik ini sebaiknya dilakukan sebelum maupun sesudah operasi koreksi. Anak dengan diameter DSV $>10 \mathrm{~mm}^{2} / \mathrm{m}^{2}$ BSA sebaiknya dilakukan pemeriksaan spirometri sebelum maupun sesudah dilakukan terapi fisik dan atau operasi koreksi. Edukasi mengenai pemberian nutrisi yang adekuat pada pasien DSV untuk memperbaiki status gizi sehingga fungsi paru menjadi lebih optimal. Diperlukan penelitian lebih lanjut dengan jumlah sampel yang lebih besar untuk melihat faktor yang paling berpengaruh terhadap fungsi paru.

\section{Daftar pustaka}

1. Sastroasmoro S, Madiyono B. Epidemiologi dan etiologi penyakit jantung bawaan. Dalam: Sastroasmoro S, Madiyono B, penyunting. Buku ajar kardiologi anak. Bima Rupa Aksara;1994.h.165-7.

2. Park MK. Pediatric Cardiology for practitioners. Edisi ke-3. St.Louis: Mosby;2006.h.131-75.

3. Nanas S, Nanas J, Papazachou O, Kassiotis C, Papamichalopoulos A, Emili JM, dkk. Resting lung function and hemodinamic parameters as predictor of exercise capacity in patient with chronic heart failure. Chest Journal.chestpubs.org. Am College Chest Physic 2003;123:1386-93.

4. Vandevoorde J, Verbanck S, Schuermans D, Kartounian J,Vincken W. FEV1/FEV6 and FEV6 as an alternative for FEV1/FVC and FVC in the spirometric detection of airway obstruction and restriction. Chest 2005;127: 1560-4.

5. Hollenberg M, Tager IB. Oxygen uptake efficiency slope: an index of exercise performance and cardiopulmonary reserve requiring only submaximal exercise. J Am Coll Cardiol 2000;36;194-201.

6. Kimball TR, Daniels SR, Meyer RA, Hannon DW, Khoury P, Schwartz DC. Relation of symptoms to contractility and defect size in infants with ventricular septal defect. Am J Cardiol 1991;67:1097-102.

7. Miller MR, Crapo R, Hankinson J. General considerations for lung function testing. Eur Respir J 2005;26:153-61.

8. Milliken JC. Ventricular septal defect. Diakses 20 February 2009. Didapat dari: http://www.eglobalmed.com/opt/ MedicalStudentdotcom/www.emedicine.com/med/topic3517.htm 
9. Putra S.T. Pendekatan diagnosis penyakit jantung bawaan non sianotik. Dalam: Putra ST, Advani N, Rahayoe $\mathrm{AU}$, penyunting. Dasar-dasar diagnosis \& tatalaksana penyakit jantung pada anak. Forum ilmiah kardiologi anak Indonesia. Simposium nasional kardiologi anak I. Jakarta: 1996:131-42.

10. Wahab AS. Penyakit jantung anak. Edisi 3. Jakarta: EGC;2003:91-134.

11. Healy F, Hanna BD, Zinman R. Pulmonary complications of congenital heart disease. Diakses 13 Januari 2010. Didapat dari: http://xa.yimg.com/kq/groups/23515872/133295256/namel Pulmonary +Complications + of + Congenital + Heart + Disease ++ PRR. 2011.pdf.

12. Boediman, Wirjodiardjo M. Anatomi dan fisiologi sistem respiratorik. Dalam: Rahajoe NN, Supriyatno B, Setyanto DB, penyunting. Buku ajar respirologi anak. Edisi pertama. Jakarta: Badan penerbit IDAI; 2008.h.150 .

13. Keane JF, Fyler DC. Ventricular septal defect. Dalam: Keane JF, Lock JE, Fyler DC, penyunting. Nadas's pediatric cardiology. Edisi ke-2. Philadelphia: Elsevier Inc; 2006.h.527-47.

14. Takken T, Giardini A, Reybrouck T, Gewillig M, HövelsGürich HH, Longmuir PE, dkk. Recommendations for physical activity, recreation sport, and exercise training in paediatric patients with congenital heart disease: a report from the exercise, basic \& translational research section of the european association of cardiovascular prevention and rehabilitation, the European congenital heart and lung exercise group, and the association for European paediatric cardiology. Eur J Preventive Cardiol 2012;19: 1034.

15. Faridi MM, Gupta P, Prakash A. Lung functions in malnourished children aged five to eleven years. Indian Pediatr 1995;32:35-42.

16. Milla CE. Association of nutritional status and pulmonary function in children with cystic fibrosis. Curr Opin Pulm Med 2004;10:505-9.

17. Yau KI, Fang LJ, Wu MH. Lung mechanics in infants with left-to-right shunt congenital heart disease. Pediatric Pulmonol 1996:42-7. Diakses 17 Juli 2011. Didapat dari: http://444.docs4you.at/Content.Node/Spezialbereiche/Infektiologie/RSVILunge_bei_CHD.df.

18. GeskeyJM, Cyran SE. Managing the morbidity associated with respiratory viral infections in children with congenital heart disease. International J Pediatr, 2012. Diakses 10 November 2012. Didapat dari: http://www. hindawi.com/journals/ijped/2012/646780/.

19. Murray DL. Acute respiratory infections and congenital heart disease. AAP Grand Rounds 2011;25;33.

20. Opotowsky AR. Abnormal spirometry in congenital heart disease. Circulation. Diakses 11 Mei 2013. Didapat dari: http://circ.ahajournals.org/content/127/8/865.extract. 